\title{
66 \\ EXPLOSIVE VOLCANOES IN THE MEDITERRANEAN AREA: HAZARDS FROM FUTURE ERUPTIONS AT VESUVIUS (ITALY) AND SANTORINI [GREECE),
}

\author{
Franco Barberi ${ }^{1, *}$, Maria Luisa Carapezza ${ }^{1}$ \\ (1) Istituto Nazionale di Geofisica e Vulcanologia, Sezione di Roma1, Rome, Italy
}

Article history

Receveid May 5, 2018; accepted December 18, 2018.

Subject classification:

Santorini and Vesuvius active volcanoes; Volcanic hazard and risk; Problems in the definition of the expected eruption.

\begin{abstract}
Santorini is the site of the famous Minoan eruption of the late Bronze Age and Vesuvius is the type locality for Plinian eruptions. Hazards from the eruption most likely to occur in the near future at these volcanoes are discussed. Downwind zones of Santorini can be affected by minor ash fallout and gas emission from a Vulcanian eruption of Nea Kameni, the most active post-caldera vent. More dangerous would be a sub-Plinian eruption from Columbus, a submarine volcano located $8 \mathrm{~km}$ NE of Santorini, whose eruption in $1649-1650$ A.D. caused several casualties in Santorini, mostly by wind transported poisoning gas. Vesuvius last erupted in 1944 and its eruptive history includes periods of long quiescence, lasting centuries or tens of centuries, interrupted by violent Plinian or sub-Plinian eruptions. A sub-Plinian eruption is the reference event in the Civil Protection emergency plan. The scenario includes a Red Zone exposed to the risk of being invaded by pyroclastic flows and that should be entirely evacuated before the eruption onset, together with some nearby areas where there is a high risk of roofs collapse by overloading of fallout tephra (nearly 700,000 persons in total). The Red Zone is encircled by the Yellow Zone exposed to pyroclastic fallout and related risk maps are here commented. Another serious risk is associated with earthquakes of the pre-eruptive unrest phase. Because of the high seismic vulnerability of the buildings within the Red Zone, many of them might collapse before the evacuation order of the Red Zone be issued. Finally, the scientific difficulty of forecasting the time evolution of the eruption precursory phenomena is discussed together with the related civil protection implications.
\end{abstract}

\section{INTRODUCTION}

Explosive eruptions consist of violent emissions of fragmented magma and gas. They cover a wide energy range, from Hawaiian to Ultra-Plinian, depending on the volume of erupted magma, its fragmentation degree, the height of the erupted column and the tephra areal dispersial [Walker, 1973]. Some explosive eruption types, i.e. Strombolian, Vulcanian and Plinian, take their name from active Italian volcanoes: Stromboli, Vulcano and Vesuvius respectively.

The major historical volcanic disasters have been produced by:

- Pyroclastic flows, generated by gravitational collapse of the eruptive column or by direct blast from an emplacing lava dome, e.g. Mt. Pelée, Martinique - 1902: 33,000 victims [Fisher and Heiken, 1982].

- Tsunami, generated by flank or caldera collapse of volcanic islands or by the entrance into the sea of huge volumes of pyroclastic flows, e.g. Unzen, Japan - 1792: 15,000 victims (also by mud flows) [Nakada et al., 1999]; Tambora, Indonesia - 1815: 10,000 victims (also by pyroclastic flows) [Brönni- 


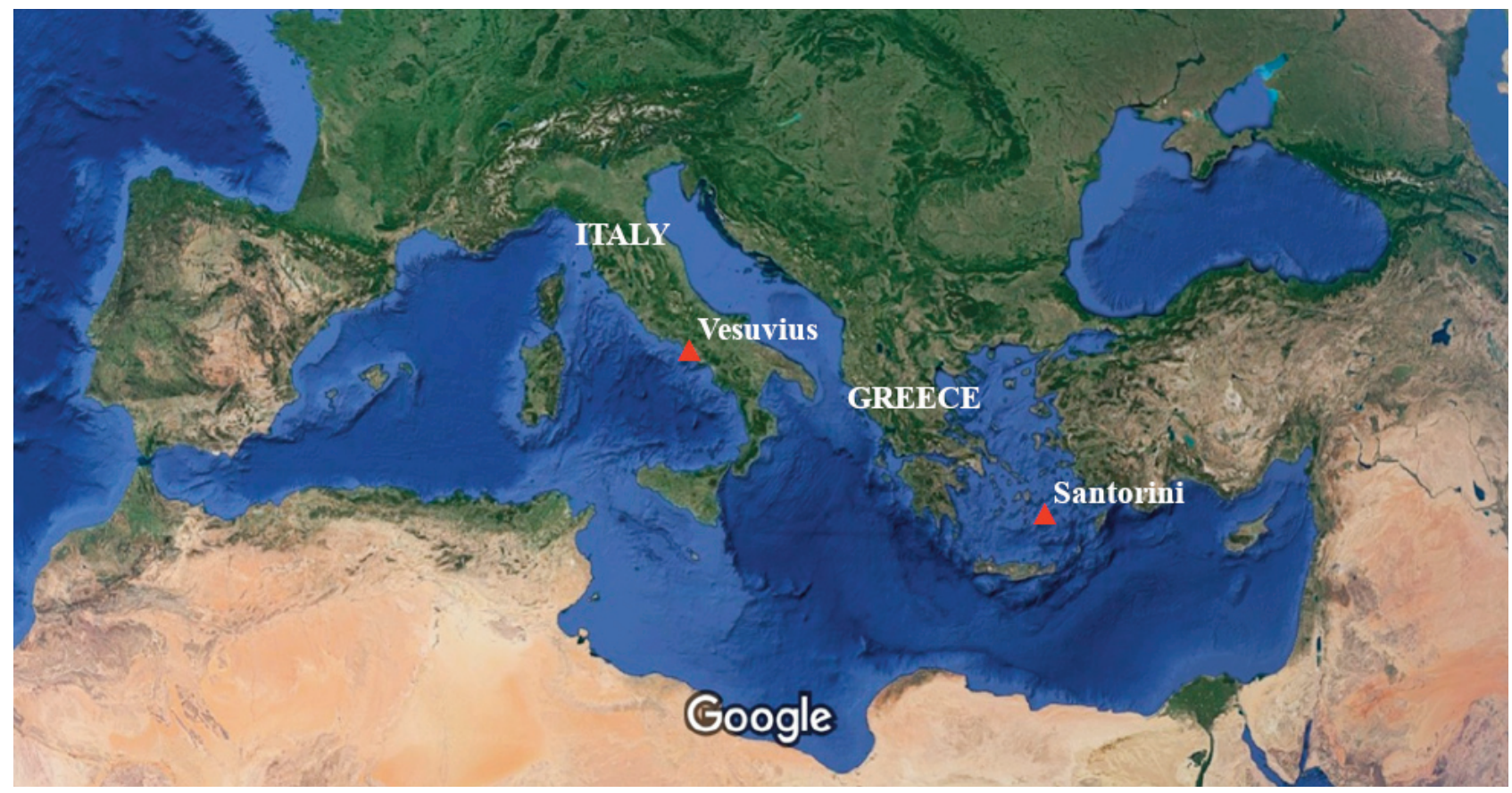

FIGURE 1. Location of Vesuvius and Santorini volcanoes in the Mediterranean area.

mann and Krämer, 2016]; Krakatau, Indonesia 1883: 36,000 victims [Brown et al., 2017].

- Lahars, generated by (i) melting of snow and ice cover of the volcano summit, e.g. Nevado del Ruiz, Colombia - 1985: 25.000 victims [Lowe et al., 1986]; (ii) flooding from crater lakes, e.g. Kelut, Indonesia - 1915: 5110 victims (also by pyroclastic flows) [Brown et al., 2017]; (iii) rain mobilization of loose tephra on steep slopes, e.g. Vesuvius, Italy 1631: 3000 victims (also by pyroclastic flows) [Rosi et al., 1993; Bertagnini et al., 2006].

- Tephra fallout, that may cause (i) damages from ballistic blocks in the proximity of the eruptive vent, e.g. Sakurajima, Japan, and (ii) roof collapses by tephra overloading in the downwind area, e.g. Pinatubo, Philippine - 1991 [Newhall et al., 1997].

Santorini in the Aegean island arc of Greece and Vesuvius in southern Italy (Figure 1) are the most famous explosive volcanoes of the Mediterranean area.

Santorini has been the site of the so-called Minoan (or Thera) eruption, a violent Plinian eruption occurred in the late Bronze age, approximately 3600 years ago [Druitt et al., 1989], that covered by thick tephra all the near emerged land and caused a large caldera collapse with associated tsunami.

Vesuvius is the type volcano for Plinian eruptions, the name coming from the letters of Plinius the Younger to Tacitus describing the famous 79 A.D. Pompei eruption.

In the Aegean island arc and in Southern Italy there are other active explosive volcanoes that also would deserve attention, such as Nysiros [Vougioukalakis and Fytikas, 2005] and Campi Flegrei [Di Vito et al., 1999]. We feel, however, that the case histories of Santorini and Vesuvius conveniently address the problem of explosive volcanoes in the Mediterranean area.

\section{SANTORINI VOLCANO}

\subsection{VOLCANOLOGICAL BACKGROUND}

After the caldera collapse generated by the huge Minoan eruption of about 1650 b.C., starting from 46 A.D. two volcanic islets (Palea- and Nea-Kameni) were progressively formed near the centre of the collapsed area (Figure 2). A likely sub-Plinian eruption occurred at Palea Kameni in 726 A.D., but it did not cause significant damages in Santorini main island [Fytikas et al., 1990]. From 1570 to 1950 A.D. six eruptions occurred at Nea Kameni, with extrusion of dacitic lava domes and flows, associated to mild Vulcanian explosions [Fytikas et al., 1990 and 1998; Pyle and Elliott, 2006].

Another active submarine volcano (Kolumbo or Columbus) is located outside the caldera, ca. $8 \mathrm{~km}$ to the NE of Santorini Island (Figure 2). Kolumbo most recent explosive eruption occurred in 1649-1650 A.D. and caused heavy losses in Santorini that was severely affected by ash fallout, volcanic gas clouds and by a tsunami generated by a caldera collapse [Fytikas et al., 1990]. 


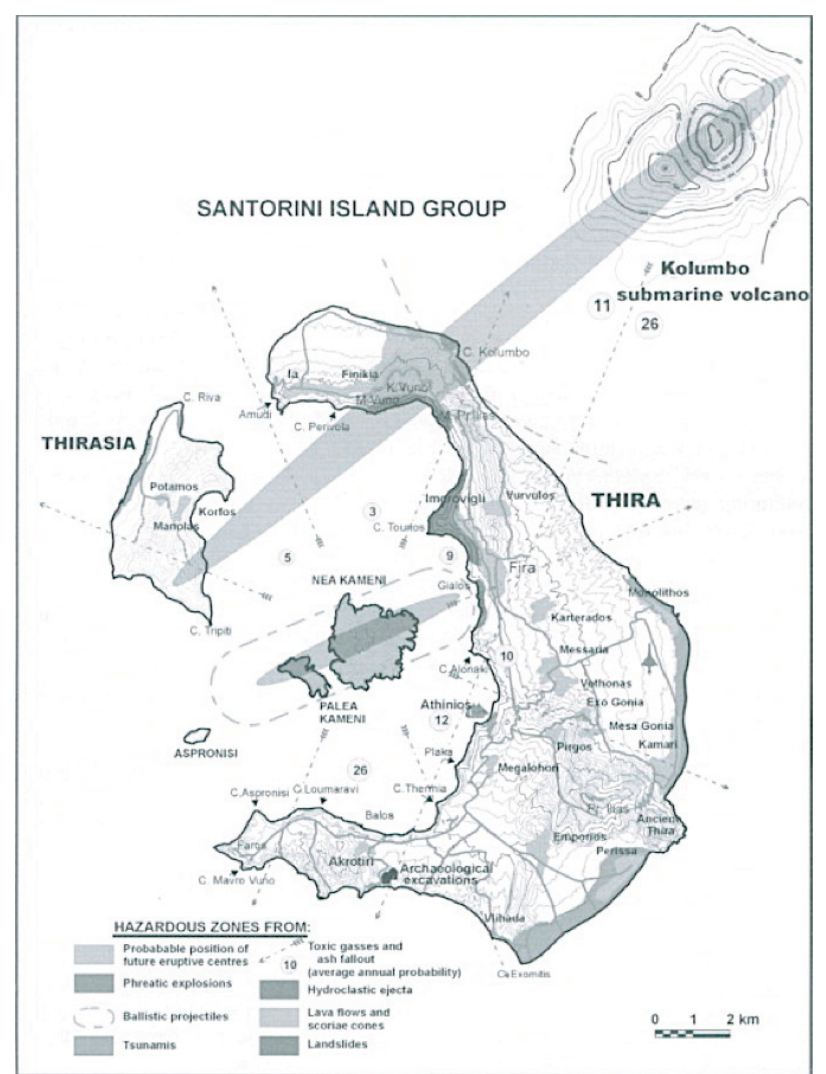

FIGURE 2. Preliminary volcanic hazard zonation map of Santorini [after Vougioukalakis and Fytikas, 2005], with location of the intra-caldera Kameni islets and of the submarine Kolumbo volcano. NE-SW aligned grey shaded areas mark the two active volcano-tectonic lines of Kameni and Kolumbo.

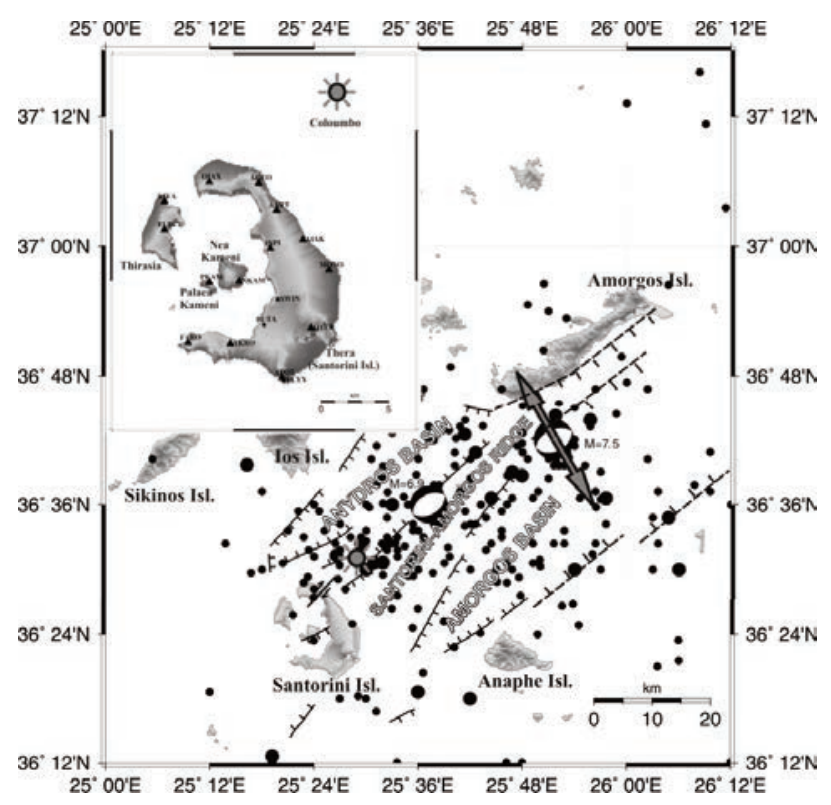

FIGURE 3. Tectonic map of the broad Santorini area. Grey star: Kolumbo submarine volcano. Solid circles: $(M \geq 4.5)$ earthquakes occurred before the 2011 Santorini unrest. The focal mechanisms of the two large 1956 earthquakes $(M=7.5$ and $M=6.9)$ are also shown. Insert: distribution of the seismological stations [after Dimitriadis et al., 2009].
All eruptions that affected Santorini in historical times have occurred from vents located on two parallel NE-SW volcano-tectonic lines: the Kameni line in the Santorini caldera, running from the Kameni islets to the main island of Santorini, and the Columbus line, running from northern Santorini to the submarine Columbus volcano (Figure 2) and extending furtherly to NE, to Amorgos island along the Santorini-Amargos ridge (Figure 3). In recent years, until 2011, these two lines had a marked contrasting behaviour, as the Columbus line has been the site of an intense seismic activity, whereas the Kameni line was characterized by an almost complete absence of seismicity [Dimitriadis et al., 2009; Tassi et al., 2013].

\subsection{THE 2011 SANTORINI UNREST}

On January 2011 an anomalous seismicity $\left(\mathrm{M}_{\mathrm{L}}\right.$ up to 3.2) began inside the Santorini caldera on the Kameni line and continued up to April 2012 (Figure 4) [Parks et al., 2013; Tassi et al., 2013]. In the same time, a rapidly expanding radial deformation was observed by GPS from a point located within the caldera to the north of Nea Kameni (Figure 4) [Newman et al., 2012].

Chemical and isotopic changes and a strong increase of $\mathrm{CO}_{2}$ and $\mathrm{HF}$ concentrations were observed in Nea Kameni fumarolic gases, suggesting an increasing input of magmatic gas [Tassi et al., 2013; Rizzo et al., 2015].

These geophysical and geochemical anomalies created concern about the possibility of a volcanic reactivation of Nea Kameni, considering that there are 15,000 permanent residents in Santorini and the population increases in summer to more than 500,000 people [Jenkins et al., 2015] being Santorini one of the most attractive touristic sites of Greece.

\subsection{ERUPTIONS THAT MAY IMPACT ON SANTORINI}

Following Jenkins et al. [2015], we think that the probability of occurrence at Santorini nowadays of a large Plinian explosive eruption, like the 1650 b.C. Minoan event, is very low, as the recurrence interval of such an eruption is approximately 15 to 20 thousand years [Dominey-Howes and Minos-Minopoulos, 2004]. Two eruptive scenarios can be considered: a "most likely" event similar to the recent historical eruptions of Nea Kameni (such as those occurred in 1866-70, 192526, 1939-40), and a "largest considered" sub-Plinian event like the 726 A.D. Palea Kameni eruption.

The "most likely" future eruption scenario includes the following hazardous events: 


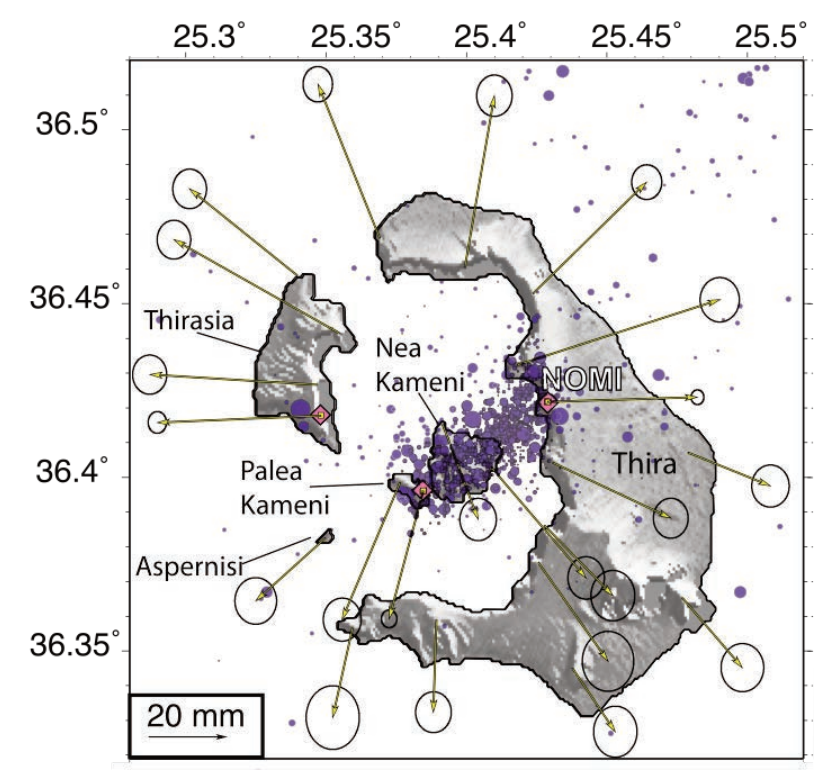

FIGURE 4. Map of the horizontal displacement field and seismicity (local magnitude $\mathrm{M}_{\mathrm{L}} \leq 3.2$; blue) during the 2011 unrest. GPS campaigns and continuous stations (magenta diamonds) show near radial displacements between 2010 and late-August 2011 [after Newman et al., 2012].

a) pre-eruption earthquakes located on the Kameni line, with $\mathrm{M}_{\mathrm{L}}$ up to 4.5-5 and focal depth mostly concentrated between 4 and $2 \mathrm{~km}$; possibility of damages to high-vulnerability buildings on Santorini island and of rock falls and landslide from instable slopes of the caldera walls;

b) pre-eruption ground deformation; the related uplift may affect the whole caldera, including its rims; however, as it consists of slow movements, no significant effects are expected on slope stability;

c) pre- or syn-eruption increase in fumarole gas emission; possible phreatic explosions with emission of steam and gas (mostly $\mathrm{CO}_{2}$ ) and ejection of fragments of pre-existing rocks with grain size from ash, to sand, to blocks; associated hazards are essentially limited to the Kameni islets and their proximity, that will have to be restricted to visitors;

d) the magmatic eruption may last up to 2 years. It will consist of a limited fallout of blocks and ash from phreatic explosions that may affect downwind Santorini zones, extrusion of viscous lava flows and domes with very limited advancing capacity and intermittent Vulcanian explosions (VEI= 3) that can eject blocks of rocks as far as 1-2 km from the vent and produce ash plumes that reach up to $3 \mathrm{~km}$ height, with a possible $\mathrm{SO}_{2}$ output of 200 tons/day. As there are no settlements within $2 \mathrm{~km}$ from the like- ly future vents, the potential impact from ballistics is not a realistic hazard, although ships and boats will have to pass not too close to Kameni islands. The main Santorini island can be invested by wind transported volcanic gas and ash. These hazards have been investigated by Jenkins et al. [2015] and their results have been used by prof. G. Zuccaro of the University of Naples and co-workers to assess the associated risk (E.U. Snowball Project). Based on the dominant wind direction, hazards are greater in the southern and south-eastern parts of Santorini and the presence in the air of fine ash and gas may cause trouble to the exposed population. However, only thin ash accumulation should occur without causing roof collapses of Santorini buildings.

The "largest considered" future eruption scenario is a sub-Plinian event, similar to the poorly known Palea Kameni eruption of 726 A.D. of unknown magnitude. Its probability of occurrence is obviously lower than the "mostly likely" scenario and likely less than 10\% [Jenkins et al., 2015]. The sequence of events a), b) and c) previously described holds also for this scenario, whereas the eruption d) scenario and related hazards obviously change. Jenkins et al. (2015) assumed a column (or plume) height of $12 \mathrm{~km}$, a 4-hour duration, a discharge rate of $1000 \mathrm{~m}^{3} / \mathrm{s}$ corresponding to an erupted mass of $3.3 \times 10^{10} \mathrm{~kg}$ (density of erupted material $=2300 \mathrm{~kg} /$ $\mathrm{m}^{3}$ ). For gas output, an average daily value of 800 tons/day of $\mathrm{SO}_{2}$ was considered. Ash and gas hazard is likely to be of concern in the downwind zones of Santorini, should such an eruption occur at Nea Kameni. According to the prevailing wind direction, higher hazard is expected in the Santorini zones located to the south and east of Nea Kameni, notably at important tourist and transports hubs. In addition, should the erupted mass be significantly high, a tsunami generating seafloor collapse might occur, which would affect facilities located within the caldera, mostly the port.

\subsubsection{SUBMARINE ERUPTION AT COLUMBUS VOL- CANO AND RELATED EVENTS}

Columbus volcano is located on the active NE trending volcano-tectonic Columbus line, belonging to the Santorini-Amorgos tectonic structure (Figure 3).

This is a very active seismic zone, which in 1956 produced two strong earthquakes with magnitude of 6.9 and 7.5 with epicentre respectively at half way between Santorini and Amorgos islands and a few km south of 
Amorgos (Figure 3). The location of earthquakes with $M$ 4.5 recorded in the last 5 decades is shown in Figure 3 [after Dimitriadis et al., 2009]. The epicentres of the best-located events, recorded between mid-2002 and mid-2005, are visible in Figure 3 that clearly indicates that the main cluster of local seismicity is located beneath the Columbus volcano, mostly at depths of 6-12 $\mathrm{km}$ [Dimitriadis et al., 2010]. Note that, before the 20112012 unrest, Santorini caldera has been seismically inactive for long time.

As previously mentioned, Columbus volcano produced in 1649 -1650 A.D. a very hazardous eruption of gas-rich silicic magma, which affected Santorini island by ash fallout, volcanic gas and a tsunami likely generated by a seafloor collapse which produced the present Columbus caldera [Fytikas et al., 1998 and references therein]. The eruption caused the death of 70 people and 1000 animals on Thera, likely mostly by volcanic poisoning gases [Vougioukalakis, 2005]. hazard is the north-eastern part of Santorini island; in the case of a volcanic reactivation of Columbus, most earthquakes will be likely located in the proximity of the submarine volcano; however also the Santorini-Amorgos seismo-tectonic line could be activated and earthquakes of significant magnitude could occur also on or near the NE extremity of Santorini. As most of these earthquakes are shallow $(\mathrm{h}<10 \mathrm{~km}$ ) there may be severe damages on vulnerable buildings;

- Ash and gas: Santorini island can be affected by ash and gas emitted by a Columbus sub-Plinian eruption, mostly in case of wind blowing towards SE and S; the local wind statistics reported by Jenkins et al. [2015] indicates that there is a significant probability that Santorini will be affected.

In addition, as occurred in the 1650 A.D. eruption, a tsunami generated either by a new caldera collapse of Columbus volcano or by the rapid entrance into the sea

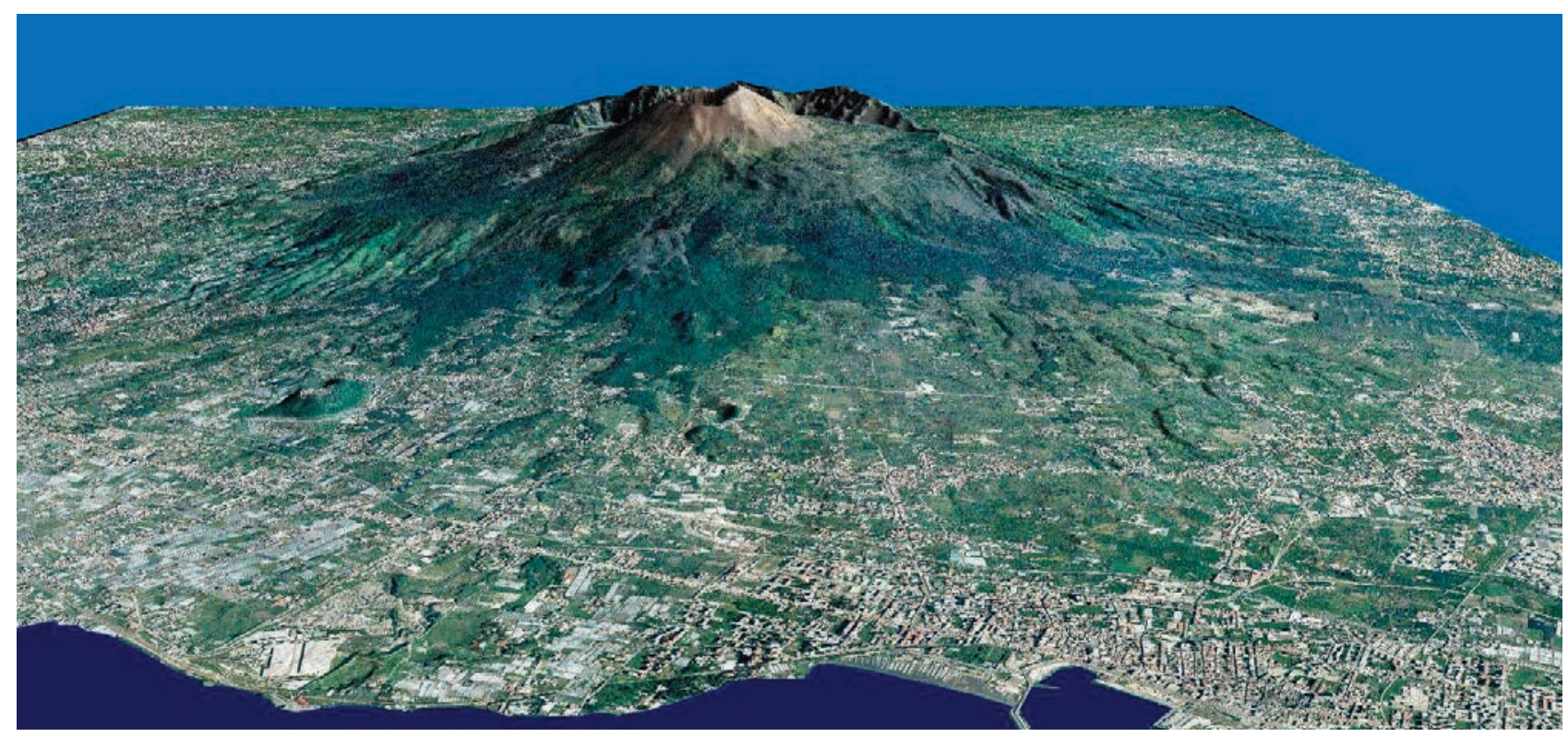

FIGURE 5. View of Vesuvius showing the Mt. Somma summit caldera and the presence of a continuous densely urbanized zone at the periphery of the volcano.

An intense hydrothermal activity with fluid temperature higher than $200{ }^{\circ} \mathrm{C}$ is still present in the Columbus caldera, which has an elliptic shape with main axis of about $3 \mathrm{~km}$, a NE-SW elongation and about $500 \mathrm{~m}$ depth [Sigurdsson et al., 2006].

The hazardous events associated with a sub-Plinian eruption at Columbus volcano similar to that of 16491650 A.D., that may have an impact on Santorini, are the following:

- Earthquakes: the zone most exposed to seismic of pyroclastic density currents [Nomikou et al., 2014] may affect the eastern coast of Santorini.

However, in the scientific literature, there is no sound hazard assessment for these events and only a qualitative estimate is possible. Considering that in 1650 A.D. significant losses were recorded in both human life and animals [Vougioukalakis and Fytikas, 2005], the repetition nowadays of a similar eruption could have a strong impact on Santorini human health, fauna, agriculture and communications. 


\section{VESUVIUS VOLCANO}

Because of the very high population density on its slope (Figure 5) and the explosive character of the expected eruption, Vesuvius is likely one of the volcanoes with the highest risk in the world.

Vesuvius is a $1281 \mathrm{~m}$ high volcanic cone, grown within the summit caldera of Mt. Somma, an older strato-volcano whose activity initiated about $37 \mathrm{ka}$ B.P. The eruptive history of the Somma-Vesuvius volcanic complex includes several periods, characterized by different activity styles and by variations in the chemical composition of erupted magmas.

The first period of the volcanic activity (from 37 to 20 ka B.P.) was characterized by mainly effusive eruptions of basic magmas, with subordinated low-energy explosive events, that built most of the Mt. Somma edifice [Andronico et al., 1995]. An important variation in the volcanic activity was recorded $18.3 \mathrm{ka}$ B.P., when the first and largest Plinian explosive eruption of trachytic magma (Pomici di Base) occurred, causing the first collapse of Mt. Somma caldera, that was successively modified and enlarged after each major explosive event [Cioni et al., 1999].

Other Plinian eruptions occurred at $8 \mathrm{ka}$ (Pomici di Mercato), $3.8 \mathrm{ka}$ (Pomici di Avellino) and A.D. 79 (Pompei eruption). Several sub-Plinian explosive eruptions are recorded in the inter-Plinian periods (the most recent in A.D. 472 and 1631), as well as several smaller explosive events (Figure 6).

Important periods of dominant effusive activity are recorded after the Pomici di Base Plinian event, in the Middle Age before the 1631 eruption and in the most recent activity period from 1631 to the last 1944 eruption (Figure 6).

Since the Pomici di Mercato Plinian eruption of 8 ka B.P., a variation is recorded in the composition of the erupted magma that becomes more silica undersaturated and alkaline; basic magmas vary from $\mathrm{k}$-tephritic to leucititic, whereas evolved magmas feeding the most explosive eruptions have a phonolitic composition generated by differentiation of the basic magma in shallow reservoirs [Cioni et al., 1999].

The eruptive history of Vesuvius is marked by long periods of quiescence that lasted centuries or tens of centuries with an awakening more and more violent the longer had been the preceding repose time [Cioni et al., 2003 and references therein].

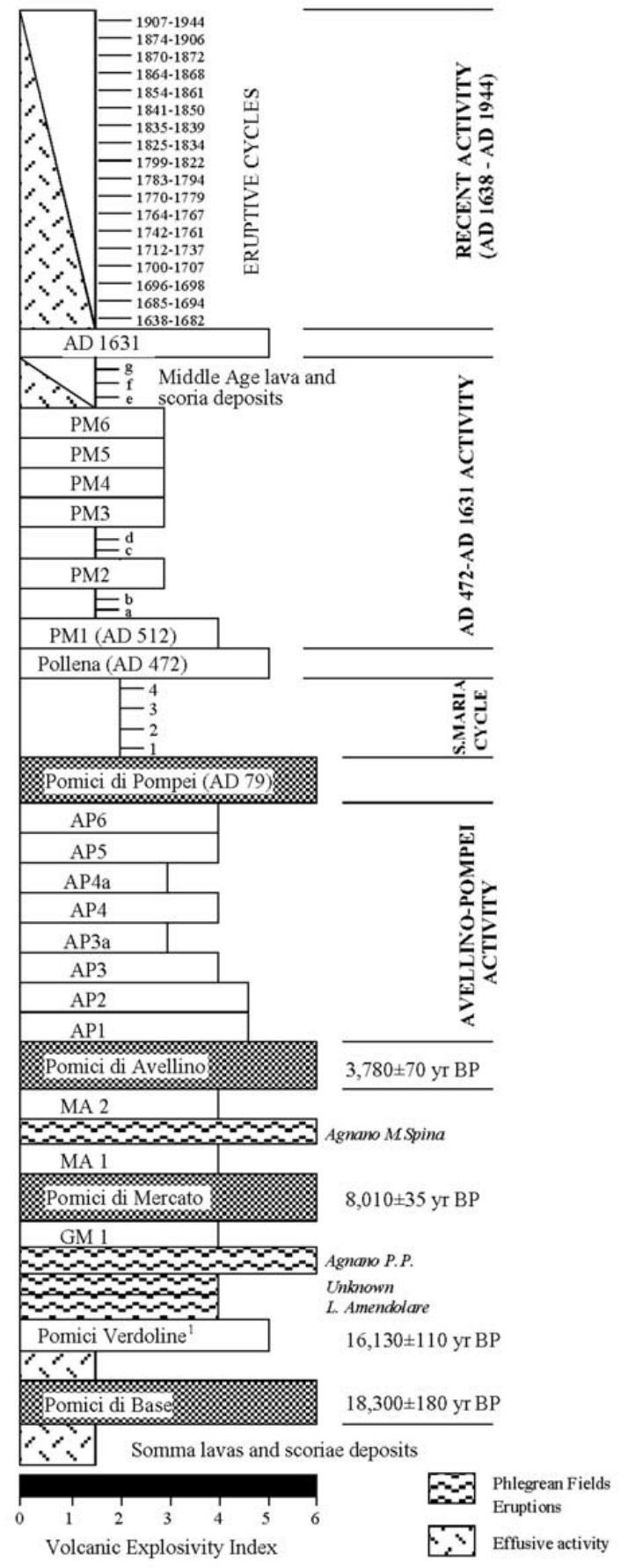

FIGURE 6. Chronostratigraphy of Vesuvius activity in the last 18 ka [after Cioni et al., 2003].

\subsection{THE EXPECTED ERUPTION AND RELATED PHE- NOMENA}

After a long period of frequent open-conduit activity, lasted over three centuries, from 1631 to 1944, Vesuvius is in a quiescent phase and it is not possible to establish how long the present repose will still last. Three-quarters of a century have already passed since its last eruption in 1944 and the volcano conduit is 


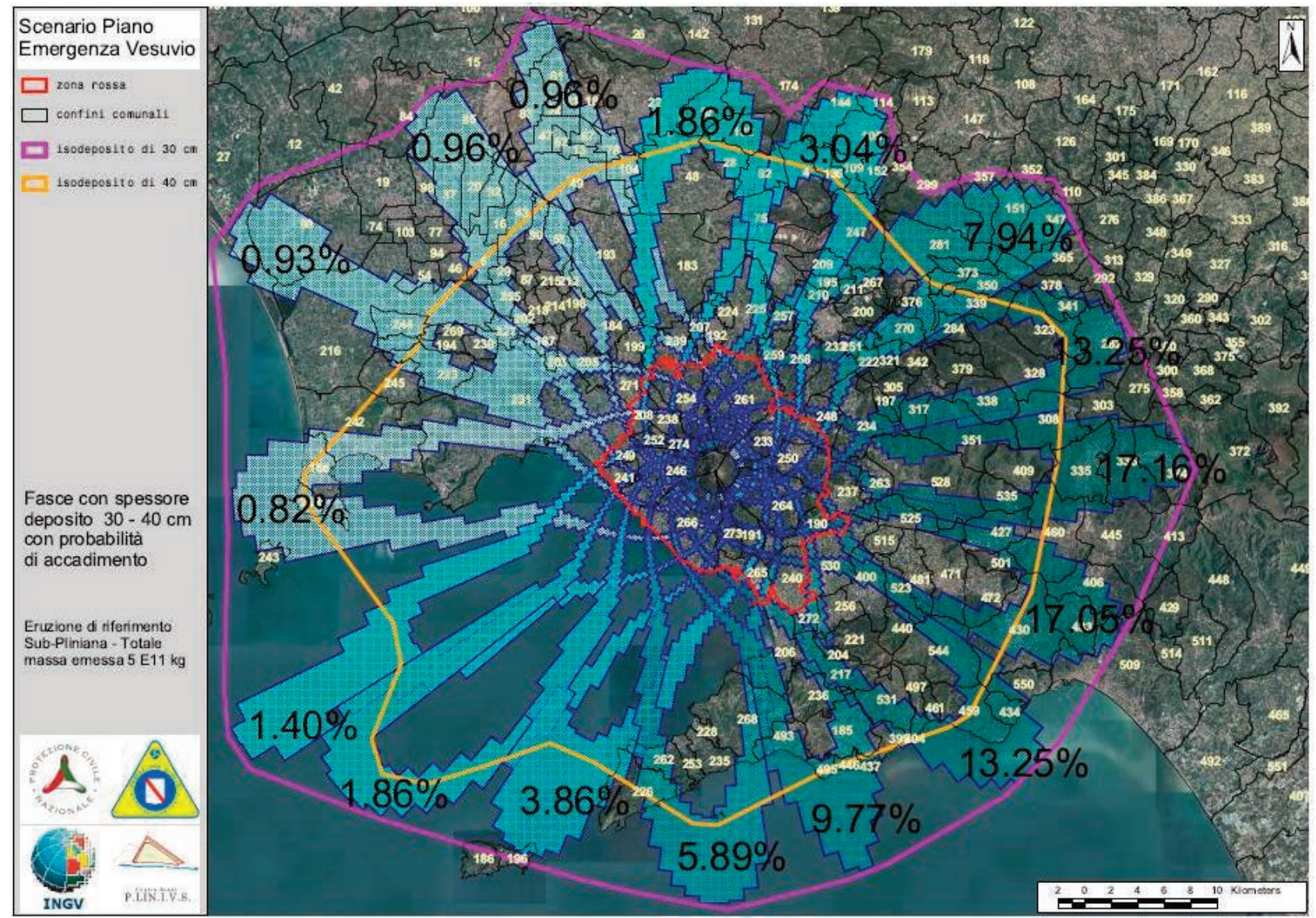

FIGURE 7. Ash fall hazard map for the sub-Plinian eruption event selected for the Civil Protection Vesuvius emergency plan [DPC, 2008 and references therein]. Yellow line $=40 \mathrm{~cm}$ isopach, purple line $=30 \mathrm{~cm}$ isopach. Percentages indicate probability that wind will disperse tephra in that direction.

presently closed. Therefore, there is a very low probability that next eruption will have the characteristics of one of the events typical of the open-conduit activity periods, dominated by the emission of lava flows with associated Strombolian or Violent Strombolian [Arrighi et al., 2001] explosions. This is the main reason why only explosive eruptions have been considered in the volcanic emergency plan for Vesuvius of the Italian Civil Protection [DPC, 1995; 2001; 2008; 2016].

The choice of the reference eruption for the definition of the scenario to be used for volcanic emergency planning is very difficult and delicate. The concept of the "maximum expected event (MEE)" was introduced by Barberi et al. [1990] and defined as the largest out of all the possible eruptions in the case of a short term reactivation of the volcanic activity of Vesuvius (20-30 years after 1990, by now nearly passed). A VEI $=4$ subPlinian eruption from the summit crater, similar but not identical to that of 1631, has been assumed as the reference event for the civil protection emergency plan [DPC, 1995] and it was maintained in all successive up- dating of the plan [DPC 2001; 2008; 2016]. The main difference from the 1631 event, is that pyroclastic flows of the 1631 eruption were confined by the Mt. Somma caldera wall and could not travel over the northern slope of the volcano [Rosi et al., 1993], whereas in the hazard scenario adopted for the emergency plan this confinement was not considered and pyroclastic flows could pass over the Mt. Somma wall.

The possibility of adopting either a less-violent VEI= 3 eruptive event (Violent Strombolian) or a more-violent VEI = 5 Plinian one, was discarded because i) it was considered very unlikely that a Violent Strombolian eruption could be produced in a closed-conduit condition of the volcano like the present one and ii) according to Marzocchi et al. [2004] the probability of having a Plinian eruption in the next 125 years or so, is estimated to $1 \%$ only.

A 1631 like sub-Plinian Vesuvius eruption includes the following main phases [Rosi et al., 1993]:

- a short opening phase, possibly with phreatic explosions and fallout of ash and blocks, mostly af- 


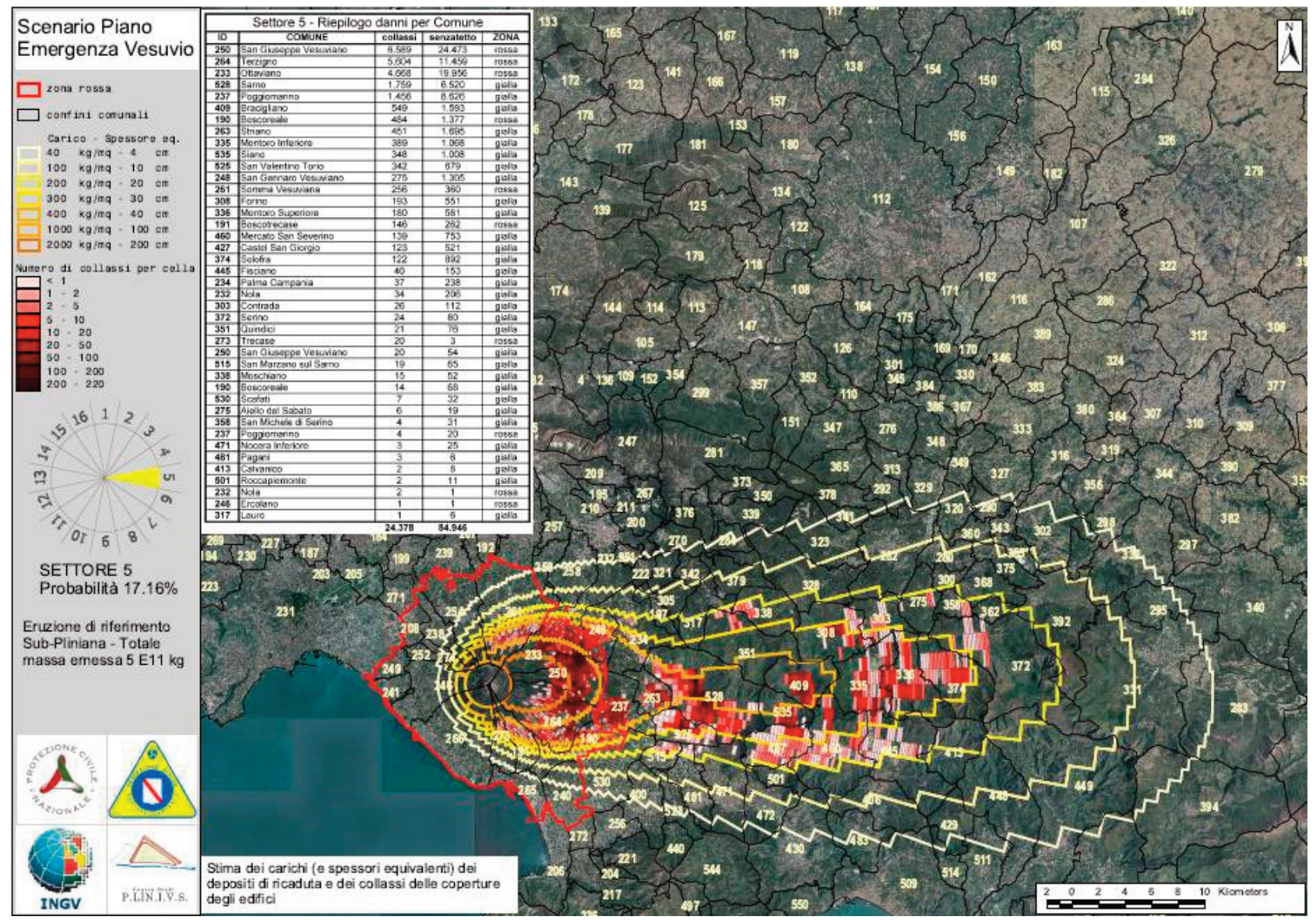

FIGURE 8. Ash fall risk map of a sub-Plinian Vesuvius eruption related to the more probable (17.16 \%) eastward wind direction. Colours indicate expected ash loads and estimated roof collapses. In the insert the expected damages are indicated for each involved municipality [DPC, 2008 and references therein].

fecting the near vent area;

- a sustained column phase lasting several hours, during which the eruptive column rises convectively to an height of $12-22 \mathrm{~km}$ (a $18 \mathrm{~km}$ height was assumed for the reference event); it is surmounted by an umbrella like cloud and produces pumice and ash fallout in the downwind zones [Cioni et al., 2003 and references therein];

- a collapsing column phase, lasting only a couple of hours, during which the eruptive column collapses by gravity, generating pyroclastic density currents of gas and volcanic particles (called hereafter pyroclastic flows) that travel at velocities of ten to hundreds of meters per second [Druitt, 1988; Gurioli et al., 2010].

Because of their high temperature, missile content, particle concentration and dynamic pressure, pyroclastic flows are the most hazardous volcanic phenomenon for human life and property [Gurioli et al., 2010 and references therein].

Results of recent researches (EU Exploris and Speed
Projects) indicate that there will be probably a significant damage reduction as far as pyroclastic flows advance far from the vent, because of the dynamic pressure attenuation caused by their impact with the barrier of the first encountered buildings of the densely urbanized circum-Vesuvian area [Zuccaro and Iannello, 2004]. Damages from pyroclastic flows could also be considerably reduced if the house openings (doors, windows) would be conveniently closed and protected [Spence et al., 2004]. Notwithstanding these possible damage reductions, the hazard associated with the emplacement of pyroclastic flows is considered so high, and so low the survival probability within the impacted area, that in the Vesuvius emergency plan the zone exposed to the risk of being invaded by pyroclastic flows is designated as the "Red Zone" and has to be totally evacuated from people and animals before the eruption onset. In the last revision of the Vesuvius emergency plan [DPC, 2016], the Red Zone has been enlarged (see Figure 11) so to include some areas having a severe risk of roofs collapse by overload of fallout tephra and bringing to nearly 


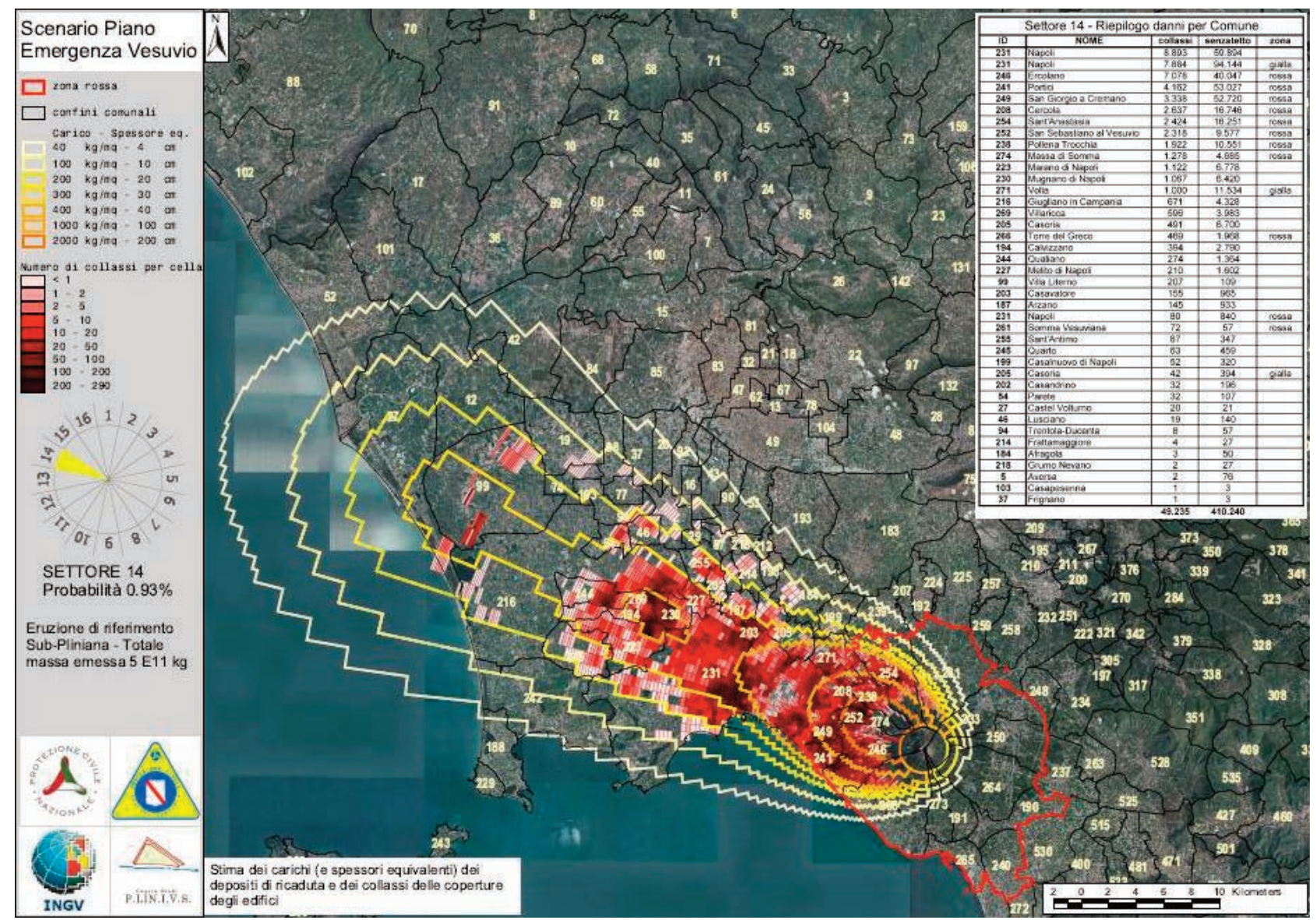

FIGURE 9. Ash fall risk map of a sub-Plinian Vesuvius eruption related to a low probability (0.93 \%) northwestward wind direction. Ash fallout will affect Naples city. Colours indicate expected ash loads and estimated roof collapses. In the insert the expected damages are indicated for each involved municipality [DPC, 2008 and references therein].

700,000 the number of people to be evacuated before the eruption onset.

The "Yellow Zone", that is the one most exposed to the ash fallout risk, encircles the Vesuvius Red Zone. The hazard map of pyroclastic fallout, elaborated by a numerical simulation made by the INGV-Osservatorio Vesuviano for a sub-Plinian eruption (column height= $18 \mathrm{~km}$; total discharged mass $=5 \times 10^{11} \mathrm{~kg}$ ) with the occurrence probability (in \%) depending on the dominant wind direction, is reported in Figure 7. This has been converted into a risk map by the Plinivs study Center of the University of Naples, using data on the vulnerability to ash load of the circum-Vesuvian building roofs. In the sector east of the crater, having the highest probability (17.16 \%) of being affected by ash fallout, a total of 24,378 roof collapses by ash load are expected, involving nearly 85,000 people (Figure 8). Should the wind blow toward NW (fortunately only $0.93 \%$ of probability) the city of Naples will be invested with 49,235 roof collapses involving 410,240 people (Figure 9). In this case distal fine ash fallout will affect also Rome cap- ital city.

The processing of wind data indicates that the probability that wind will maintain the same blowing direction decreases rapidly with time and so only at the moment of the eruption onset it will be possible to know which is the zone that will be mostly affected by ash fallout. This implies that protection measures for the exposed population can be adopted only at the moment of the eruption onset [DPC, 2008].

Another significant hazard of a Vesuvius sub-Plinian eruption is related to the generation of syn- or posteruptive mud flows (lahars) generated by rain mobilization of loose tephra accumulated on the Vesuvius cone and on the steep slopes of downwind Apennine reliefs, as occurred in all historical sub-Plinian Vesuvius eruptions. The dispersal area of lahars generated from the Vesuvius cone coincides substantially with the Red Zone that should have been evacuated before the eruption onset. More difficult is to adopt proper civil protection measures in distal downwind towns and villages, where lahar hazard will long persist also after the erup- 


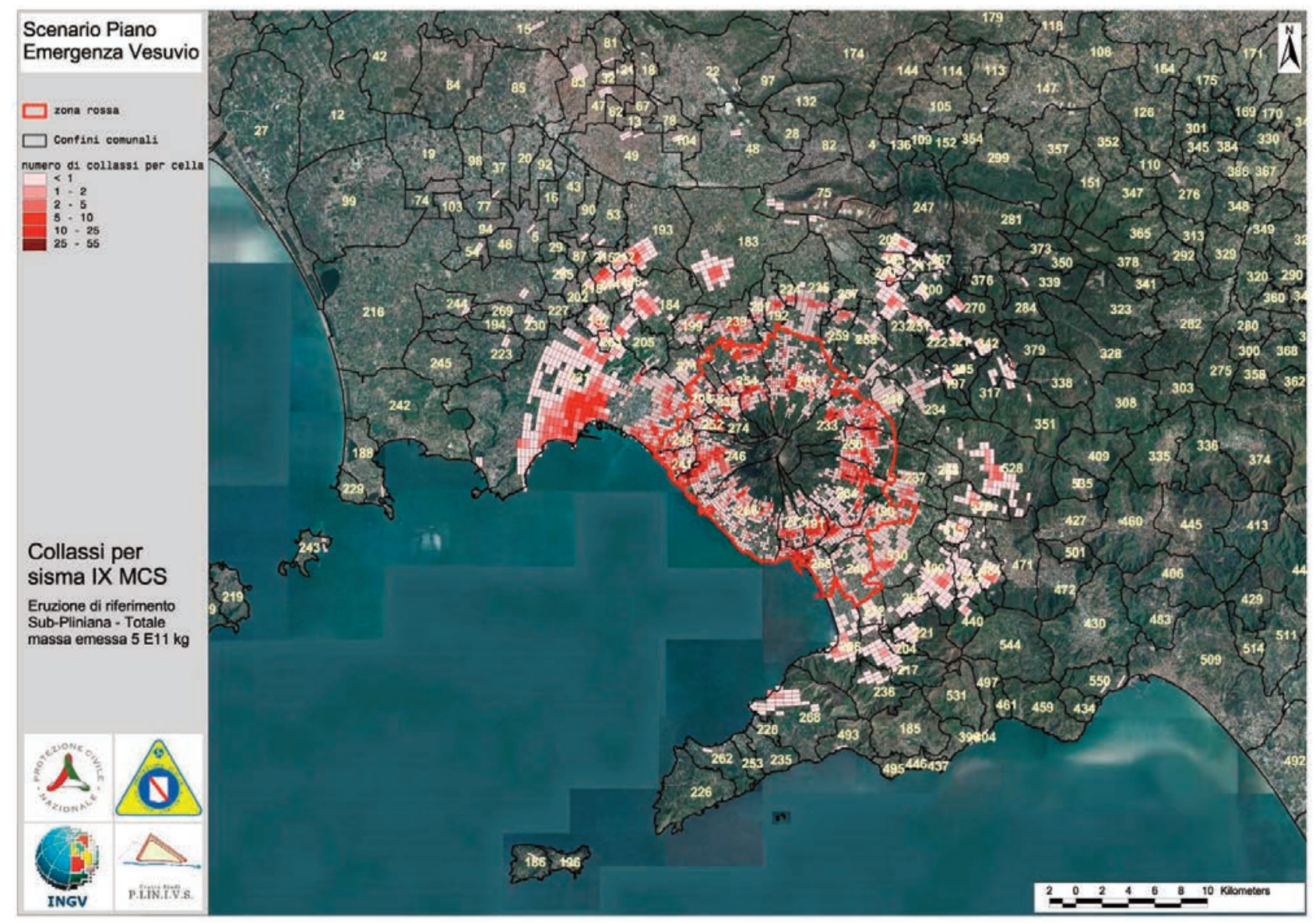

FIGURE 10. Seismic risk map of Vesuvius. Colours indicate the number of building collapses that might be generated by an earthquake with an epicentre intensity of IX MCS located in the crater zone [DPC, 2008 and references therein].

tion end.

A further dramatic problem is related to the earthquakes that will most likely occur during the pre-eruptive reactivation phase of the volcano. The maximum estimated event is a $\mathrm{M}=5.5$ earthquake with 3-4 km ipocentral depth and epicentre in the crater area (intensity at the epicentre = IX MCS) [DPC, 2008 and references therein]. Based on the seismic vulnerability of circum-Vesuvian buildings, Zuccaro et al. [2008 and 2010] estimated that such an earthquake would produce severe damages in the Red Zone (Figure 10).

A double problem then arises: (i) civil protection might have to face a serious seismic emergence just before issuing the Red Zone evacuation order for impending eruption, and (ii) evacuation of the Red Zone could be severely hindered because the ruins of collapsed and partly collapsed buildings caused by the earthquakes, may hamper the road practicability; then Red Zone evacuation might not be completed at the moment of the eruption onset.

\section{DISCUSSION AND CONCLUSIONS}

Volcanic unrest process leading to the eruptive reactivation of a quiescent volcano includes the following main phenomena:

- Ground deformation, with reduction of the affected area and increasing localized uplift as far as the magma approaches the surface;

- Anomalous seismicity, with concentration of the epicentres in the zone where the eruptive vent will open;

- Increase of the magmatic gas discharge from existing or newly created fumaroles, and compositional changes in the emitted gas with progressive enrichment in the more soluble species (e.g. $\mathrm{HCl}$, $\mathrm{HF}$ ) as far as the magma rises up. In the relatively frequent case in which the fumarolic gas is fed by a boiling geothermal aquifer, heated by magmatic gas, its temperature is buffered by the coexistence of liquid water and steam and does not increase during the unrest phase. 


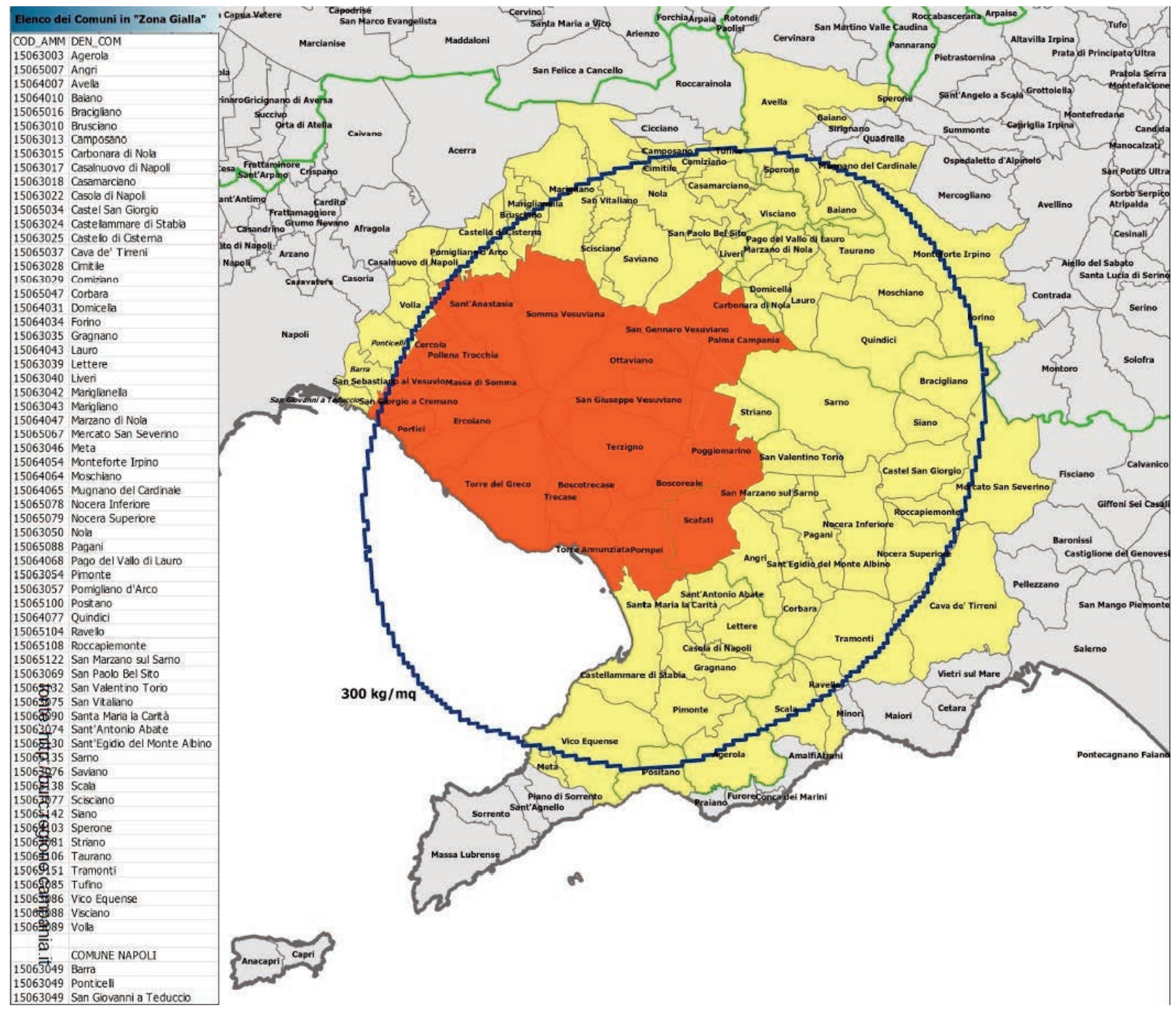

FIGURE 11. Limits of the Red Zone exposed to the risk of pyroclastic flows and to severe risk of tephra fallout as indicated in the Vesuvius emergency plan of 2016. The black circle indicates the ash fall limit of $300 \mathrm{~kg} / \mathrm{m}^{2}$ [after DPC, 2016].

In a well-monitored volcano, where geophysical and geochemical data are continuously recorded and processed in nearly real-time, these precursory phenomena will be certainly recorded before the eruption onset. However, it is very difficult to recognize exactly the moment in which the process toward an impending eruption becomes irreversible and to estimate the time still lacking to the eruption onset. An excessive anticipation of the alert for impending eruption might lead to a false alarm, but waiting too long may lead to an alert issued so near to the eruption onset to become in practice a failed alarm, at least in volcanoes like Vesuvius, where several days (at least 3) are needed to complete the evacuation of the population from the threatened zones.

Such a dramatic dilemma exists also for Santorini, but only for a Kolumbo eruption, being the impact from a Nea Kameni eruption not so high to require a preeruption evacuation. In this dilemma, our feeling is that a false alarm, also considering its severe social an economic impact, has to be preferred to a failed alarm that may cause the loss of very many lives. We also think that national and local authorities, as well as the population living in the risk zones, should be made aware of this limited capacity of volcanologists in estimating the time evolution of the volcanic precursory phenomena.

We have shown in this paper that the definition of the eruptions expected either at Santorini and Vesuvius, is based on a review, with a rough probabilistic estimate, of their respective eruptive histories. This is the approach used by volcanologists for assessing volcanic hazards, and this implies that so far volcanologists are not able 
to estimate the type and intensity of the expected eruption from the characteristics of the geophysical and geochemical phenomena recorded during the volcanic unrest. We feel that to gain this capability is the main challenge toward the future of the volcanology research.

\section{REFERENCES}

Andronico, D., G., Calderoni, R., Cioni, A., Sbrana, R., Sulpizio, R., Santacroce (1995). Geological map of Somma-Vesuvius Volcano. Per. Mineral. 64, 77-78.

Arrighi, S., C., Principe, M., Rosi (2001). Violent Strombolian and subplinian eruptions at Vesuvius during post-1631 activity. Bull. Volcanol., 63, 126150.

Barberi, F., G., Macedonio, M.T., Pareschi, R., Santacroce (1990). Mapping the tephra fallout risk: An example from Vesuvius (Italy). Nature, 344, 142-144.

Bertagnini, A., Cioni, R., Guidoboni, E., Rosi, M., Neri, A., Boschi, E. (2006). Eruption early warning at Vesuvius: The A.D. 1631 lesson. Geophys. Res. Lett., 33-18, doi.org/10.1029/2006GL027297.

Brönnimann, S., D., Krämer (2016). Tambora and the "Year Without a Summer" of 1816. A Perspective on Earth and Human Systems Science. Geographica Bernensia G90, pp. 48, doi:10.4480/GB2016.G90.01.

Brown, S.K., S.F., Jenkins, R.S.J., Sparks, H., Odbert, M.R., Auker (2017). Volcanic fatalities database: analysis of volcanic threat with distance and victim classification. J. Appl. Volcanol., 6-15, doi: 10.1186/s13617-017-0067-4.

Cioni, R., R., Santacroce, A., Sbrana (1999). Pyroclastic deposits as a guide for reconstructing the multistage evolution of the Somma-Vesuvius Caldera. Bull. Volcanol., 61-4, 207-222.

Cioni, R., A., Longo, G., Macedonio, R., Santacroce, A., Sbrana, R., Sulpizio, D., Andronico (2003). Assessing pyroclastic fall hazard through field data and numerical simulations: Example from Vesuvius. J. Geopys. Res., 108-B2, 2063. Doi: 10.1029/2001JB000642.

Dimitriadis, I., E., Karagianni, D.G., Panagiotopoulos, C., Papazachos, P., Hatzidimitriou, M., Bohnhoff, M., Rische, T., Meier (2009). Seismicity and active tectonics at Coloumbo Reef (Aegean Sea, Greece): monitoring an active volcano at Santorini Volcanic
Center using a temporary seismic network. Tectonophys., 465, 136-149.

Dimitriadis, I., C., Papazachos, D.G., Panagiotopoulos, P., Hatzidimitriou, M., Bohnhoff, M., Rische, T., Meier (2010). P and S velocity structures of the SantoriniColoumbo volcanic system (Aegean Sea, Greece) obtained by non-linear inversion of travel times and its tectonic implications. J. Volcanol. Geotherm. Res., 195, 13-30.

DPC (1995). Pianificazione Nazionale d'Emergenza dell'Area Vesuviana. Dipartimento della Protezione Civile, Roma (in Italian).

DPC (2001). Aggiunte e varianti alle parti A3, B, C1 e C2 della Pianificazione Nazionale d'Emergenza dell'Area Vesuviana. Dipartimento della Protezione Civile, Roma (in Italian).

DPC (2008). Scenari eruttivi e livelli di allerta per il Vesuvio. Dipartimento della Protezione Civile, Roma (in Italian).

DPC (2016). Aggiornamento del Piano nazionale di emergenza per il Vesuvio. In: http://www.protezionecivile.gov.it/.

Di Vito, M.A., R., Isaia, G., Orsi, J., Southon, S., de Vita, M., D’Antonio, L., Pappalardo, M., Piochi (1999). Volcanism and deformation since 12,000 years at the Campi Flegrei caldera (Italy). J. Volcanol. Geotherm. Res., 91 2-4, 221-246.

Dominey-Howes, D., D., Minos-Minopoulos (2004). Perceptions of hazard and risk on Santorini. J. Volcanol. Geotherm. Res., 137-4, 285-310.

Druitt, T.H. (1988). Pyroclastic density currents. Geol. Soc., London, Spec. Publ., 145, 145-182. Doi: 10.1144/GSL.SP.1996.145.01.08.

Druitt, T.H., R.A., Mellors, D.M., Pyle, R.S.J., Sparks (1989). Explosive volcanism on Santorini, Greece. Geol. Magaz., 126, 95-126.

Fytikas, M., N., Kolios, G.E., Vougioukalakis (1990). Post-Minoan activity of the Santorini volcano: Volcanic hazard and risk, forecasting possibilities. In: Hardy D.A., Keller J., Galanopoulos V.P., Flemming N.C., Druitt T.H. (eds.), Thera and the Aegean world III. The Thera Foundation, London, 183-198.

Fytikas, M., G., Vougioukalakis, P., Dalampakis, J.M., Bardintzeff (1998). Volcanic hazard assessment and civil defence planning on Santorini. In: Casale, R., Fytikas, M., Sigvaldasson, G., Vougioukalakis, G. (eds.), Volcanic Risk: the European Laboratory Volcanoes. The European Commission, Directorate General: Science, Research and Development, En- 
vironment and Climate Programme, 92-828-03791, 339-351.

Fisher, R.V., G., Heiken (1982). Mt. Pelée, Martinique: May 8 and 20, 1902. Pyroclastic flows and surge, J. Volcanol. Geotherm. Res., 13, 339-371.

Gurioli, L., R., Sulpizio, R., Cioni, A., Sbrana, R., Santacroce, W., Luperini, D., Andronico (2010). Pyroclastic flow hazard assessment at Somma-Vesuvius based on the geological record. Bull. Volcanol., 72, 1021-1038.

Jenkins, S.F., S., Barsotti, T.H., Hincks, A., Neri, J.C., Phillips, R.S., Sparks, T., Sheldrake, G., Vougioukalakis (2015). Rapid emergency assessment of ash and gas hazard for future eruptions at Santorini Volcano, Greece. J. Appl. Volcanol., 4-16, https://doi.org/10.1186/s13617-015-0033-y.

Lowe, D.R., S.N., Williams, H., Leigh, C.B., Connort, J.B., Gemmell, R.E., Stoiber (1986). Lahars initiated by the 13 November 1985 eruption of Nevado del Ruiz, Colombia. Nature 324, 51-53. Doi:10.1038/324051a0.

Marzocchi, W., L., Sandri, P., Gasparini, C. Newhall, E., Boschi (2004). Quantifying probabilities of volcanic events: the example of volcanic hazard at Mount Vesuvius. J. Geophys. Res., 109-B11201. https://doi.org/10.1029/2004JB003155.

Nakada, S., H., Suzuki, T., Furuya (1999). Volcanic hazard at Unzen, Japan. Landslides of the world (editor: Kyoji Sassa). Kyoto University Press, 311316.

Newhall C.G.,, II, Hendley J.W., P.H. Stauffer (1997). The Cataclysmic 1991 Eruption of Mount Pinatubo, Philippines. USGS Report, Series 113-97.

Newman, A. V., Stiros, S., Feng, L., Psimoulis, P., Moschas, F., Saltogianni, V., ... D., Vamvakaris (2012). Recent geodetic unrest at Santorini caldera, Greece. Geophys. Res. Lett., 39, L06309. Doi:10.1029/2012GL051286.

Nomikou, P., S., Carey, K.L.C., Bell, D., Papanikolaou, K., Bejelou, K., Cantner, D., Sakellariou, I., Perros (2014). Tsunami hazard risk of a future volcanic eruption of Kolumbo submarine volcano, NE of Santorini Caldera, Greece. Nat. Haz., 72-3, 13751390.

Parks, M.M., S., Caliro, G., Chiodini, D.M., Pyle, T.A., Mather, K., Berlo, M., Edmonds, J., Biggs, P., Nomikou, C., Raptakis (2013). Distinguishing contributions to diffuse $\mathrm{CO}_{2}$ emissions in volcanic areas from magmatic degassing and thermal decar- bonation using soil gas ${ }^{222} \mathrm{Rn}-\delta^{13} \mathrm{C}$ systematics: Application to Santorini volcano, Greece. Earth Planet. Sci. Lett., 377-378, 180-190. Doi:10.1016/j.epsl.2013.06.046.

Pyle, D.M., J.R., Elliott (2006). Quantitative morphology, recent evolution, and future activity of the Kameni Islands volcano, Santorini, Greece. Geosphere 2, 253-268.

Rizzo, A., F., Barberi, M.L., Carapezza, A., Di Piazza, L., Francalanci, F., Sortino, W., D’Alessandro (2015). New mafic magma refilling a quiescent volcano: evidence from He-Ne-Ar isotopes during the 20112012 unrest at Santorini, Greece. Geochem., Geophys. Geosyst. http://dx.doi.org/10.1002/2014GC005653.

Rosi, M., C., Principe, R., Vecci (1993). The 1631 Vesuvius eruption. A reconstruction based on historical and stratigraphical data. J. Volcanol. Geotherm. Res., 58, 151-182.

Sigurdsson, H., Carey, S., Alexandri, M., Vougioukalakis, G., Croff, K., Roman, C., Goguo, A. (2006). Marine investigations of Greece's Santorini volcanic field. EOS, Trans. Am. Geophys. Un., 87(34), 337-342.

Spence, R.J.S., G., Zuccaro, S.M., Petrazzuoli, P.J., Baxter (2004). The resistance of buildings to pyroclastic flows: analytical and experimental studies and their applications to Vesuvius. ASCE's Natural Hazards Review, 5-1. https://doi.org/10.1061/(ASCE)15276988(2004)5:1( 48).

Tassi, F., O., Vaselli, C.B., Papazachos, L., Giannini, G., Chiodini, G.E., Vougioukalakis, E., Karagianni, V., Vamvakaris, D., Panagiotopoulos (2013). Geochemical and isotopic changes in the fumarolic and submerged gas discharges during the 2011-2012 unrest at Santorini caldera (Greece). Bull. Volcanol., 75, 115, doi:10.1007/s00445-013-0711-8.

Vougioukalakis, G.E. (2005). Santorini. Blue Volcanoes, Thira Municipal Corporation, pp. 79.

Vougioukalakis, G.E., M., Fytikas (2005). Volcanic hazards in the Aegean area, relative risk evaluation, monitoring and present state of the active volcanic centers. Developm. Volcanol., 7, 161-183.

Walker, P.L.G. (1973). Explosive volcanic eruptions: a new classification scheme. Geolog. Rundschau, 62-2, 431-46.

Zuccaro, G., D., Iannello (2004). Interaction of pyroclastic flows with building structures in an urban settlement: a fluid-dynamic simulation impact 


\section{BARBERI ET AL.}

model. J. Volcanol. Geotherm. Res., 133, 1-4, 345352.

Zuccaro, G., F., Cacace, R.J.S., Spence, P.J., Baxter (2008). Impact of explosive eruption scenarios at Vesuvius. J. Volcanol. Geotherm. Res., 178-3, 416453.

Zuccaro, G., F., Barberi, F., Cacace (2010). Risk associated to pre-eruption earthquakes: a relevant problem in Vesuvius emergency planning. Cities on Volcanoes 6, Tenerife, Abstract Volume, 4.3-0-04, 27.

CORRESPONDING AUTHOR: Franco BARBERI,

Istituto Nazionale di Geofisica e Vulcanologia Sezione di Roma 1 email: barberi@uniroma3.it 